\title{
Transgenic mice overexpressing insulin-like growth factor-II in $\beta$ cells develop type 2 diabetes
}

\author{
Jean-Christophe Devedjian, Monica George, Alba Casellas, Anna Pujol, \\ Joana Visa, Mireia Pelegrín, Laurent Gros, and Fatima Bosch
}

Department of Biochemistry and Molecular Biology, School of Veterinary Medicine, Universitat Autònoma de Barcelona, 08193 Bellaterra, Spain

Address correspondence to: Fatima Bosch, Department of Biochemistry and Molecular Biology, School of Veterinary Medicine, Edifici V, Universitat Autònoma de Barcelona, 08193 Bellaterra, Spain. Phone: 34-93-5811043; Fax: 34-93-5812006;

E-mail: fatima.bosch@blues.uab.es.

Received for publication October 29, 1998, and accepted in revised form February 2, 2000.

During embryonic development, insulin-like growth factor-II (IGF-II) participates in the regulation of islet growth and differentiation. We generated transgenic mice (C57BL6/SJL) expressing IGF-II in $\beta$ cells under control of the rat Insulin I promoter in order to study the role of islet hyperplasia and hyperinsulinemia in the development of type 2 diabetes. In contrast to islets from control mice, islets from transgenic mice displayed high levels of IGF-II mRNA and protein. Pancreases from transgenic mice showed an increase in $\beta$-cell mass (about 3-fold) and in insulin mRNA levels. However, the organization of cells within transgenic islets was disrupted, with glucagon-producing cells randomly distributed throughout the core. We also observed enhanced glucose-stimulated insulin secretion and glucose utilization in islets from transgenic mice. These mice displayed hyperinsulinemia, mild hyperglycemia, and altered glucose and insulin tolerance tests, and about $30 \%$ of these animals developed overt diabetes when fed a high-fat diet. Furthermore, transgenic mice obtained from the N1 backcross to C57KsJ mice showed high islet hyperplasia and insulin resistance, but they also developed fatty liver and obesity. These results indicate that local overexpression of IGF-II in islets might lead to type 2 diabetes and that islet hyperplasia and hypersecretion of insulin might occur early in the pathogenesis of this disease.

J. Clin. Invest. 105:731-740 (2000).

\section{Introduction}

Insulin-like growth factor-II (IGF-II) is a growth-promoting polypeptide that shares a high degree of structural homology with insulin. IGF-II is synthesized primarily by the liver, but it is also produced locally by many tissues, where it acts in an autocrine or paracrine manner (1-3). It is expressed at high levels during embryonic development, but its expression is progressively extinguished in most tissues after birth (1-3). In the developing pancreas, IGF-II is involved in the regulation of islet growth and differentiation and is much more abundant than IGF-I (4). Furthermore, in cultured fetal and neonatal rat islets, IGF-II stimulates DNA synthesis $(5,6)$. In adults, IGF-II has been shown to colocalize with insulin in the $\beta$ cells of human and rat pancreas $(7,8)$. Furthermore, in Goto-Kakizaki (GK) rats (a model of mild type 2 diabetes without obesity), greater amounts of a high-molecular-weight form of IGF-II were found in pancreatic extracts from 2- and 6-month-old GK rats than in extracts from 1-monthold GK and control rats $(8,9)$. Moreover, more IGF-II mRNA was detected in starfish-shaped islets of GK rats than in either GK rat islets with normal structure or islets of control rats (8).

Type 2 diabetes mellitus is characterized by decreased response of the liver and peripheral tissues to insulin (insulin resistance) and by inadequate compensatory insulin secretory response $(10,11)$. Hyperinsulinemia in the fasting state is observed relatively early in type 2 diabetes, but it is believed to be a secondary response that compensates for the insulin resistance. However, it has been suggested $(11,12)$ that hypersecretion of insulin is a primary defect in type 2 diabetes and that insulin resistance develops secondarily to the chronic hyperinsulinemia. In Pima Indians, the plasma insulin response to either oral or intravenous glucose administration is significantly greater than in Caucasians (13). This suggests that primary, not compensatory, hypersecretion of insulin by the pancreatic $\beta$ cells may be a basic genetic defect for type 2 diabetes in this population. Similarly, fasting and postprandial hyperinsulinemia precede the development of insulin resistance in individuals with juvenile-onset obesity (14) and in a variety of animal models of obesity and diabetes, including normal rats with ventromedial hypothalamus lesions (15) and Zucker diabetic fatty (ZDF) rats (16). In the sand rat, a model of nutrition-induced diabetes, hyperinsulinemia is the initial effect of overeating and is associated with a dramatic decrease in insulin-induced receptor tyrosine kinase activity in both liver and muscle in vitro and in vivo (17). Moreover, chronic physiological euglycemic hyperinsuline- 
mia persisting for 3-5 days can induce severe insulin resistance in healthy young subjects with normal glucose tolerance (18). Furthermore, patients with insulinoma display degrees of insulin resistance that are directly related to the extent of their hyperinsulinemia $(19,20)$. Similarly, transgenic mice that overexpress the human insulin gene develop insulin resistance subsequent to hyperinsulinemia $(21,22)$.

In this study we have developed transgenic mice overexpressing IGF-II under control of the rat insulin-I promoter (RIP-I/IGF-II) to determine whether an increase in this factor in the pancreas may lead to islet hyperplasia, and if this is the case, to determine the role of increased $\beta$-cell mass and insulin secretion in the development of type 2 diabetes.

\section{Methods}

Generation of transgenic mice. The RIP-I/IGF-II chimeric gene was obtained by introduction of a $0.72-\mathrm{kb} E c o \mathrm{RI}$ fragment containing the entire mouse IGF-II cDNA (23) at the EcoRI site in an RIP-I/ $\beta$-globin expression vector (24). This chimeric gene was microinjected into fertilized mouse eggs from a C57BL6/SJL background. The general procedures used for microinjection and detection were as described (25). Transgenic mice expressing the RIP-I/IGF-II chimeric gene with a C57BL6/SJL genetic background were also backcrossed to C57KsJ mice (The Jackson Laboratory, Bar Harbor, Maine, USA), and the N1 generation was analyzed. In the experiments described below, heterozygous male mice were used. Mice were fed ad libitum with a standard diet (Panlab, Barcelona, Spain) and kept under a 12-hour light/12hour-dark cycle (lights on at 0800 hours). When stated, mice were kept in individual cages and fed a high-fat diet (TD 88137; Harlan Teklad Laboratory, Madison, Wisconsin, USA) for up to 2 months.

RNA analysis. Total RNA was obtained from pancreas by the guanidine isothiocyanate method (26). RNA samples $(30 \mu \mathrm{g})$ were electrophoresed on a $1 \%$ agarose gel containing $2.2 \mathrm{M}$ formaldehyde. Northern blot was hybridized to an $\alpha-{ }^{32} \mathrm{P}-$ labeled $0.72-\mathrm{kb}$ EcoRI fragment containing the entire IGF-II cDNA, or to a $0.36-\mathrm{kb}$ $S m a I / X h o I$ fragment corresponding to human insulin cDNA. The $\beta$-actin probe corresponded to a $1.3-\mathrm{kb}$ EcoRI fragment of rabbit cDNA. These probes were labeled using $\left[\alpha_{-}{ }^{32} \mathrm{P}\right] \mathrm{dCTP}$, following the method of random oligopriming described by the manufacturer (Roche Molecular Biochemicals, Mannheim, Germany). Nylon membranes (Roche Molecular Biochemicals) were placed in contact with Kodak XAR-5 film.

Protein analysis. For immunohistochemical detection of IGF-II, insulin, glucagon, and somatostatin, pancreases from control and transgenic mice were fixed for 12-24 hours in formalin, embedded in paraffin, and sectioned. Sections were incubated overnight at $4^{\circ} \mathrm{C}$ with either a rabbit anti-human IGF-II antibody (GroPep Pty. Ltd., North Adelaide, Australia) diluted to $1: 100$, a guinea pig anti-porcine insulin antibody (DAKO Corp., Carpinteria, California, USA) diluted to
1:100, a rabbit anti-human glucagon antibody (ICN Biochemicals Inc., Cleveland, Ohio, USA) diluted to $1: 4,000$, or with a rabbit anti-human somatostatin antibody (ICN Biochemicals Inc.) diluted to 1:2,000. As secondary antibodies, rabbit anti-guinea pig IgG coupled to peroxidase (Roche Molecular Biochemicals), or biotinylated goat anti-rabbit antibody and avidinbiotin complex (ABC; Vector Laboratories, Burlingame, California, USA) were used. 3'3'-diaminobenzidine or 3-amino-9-ethylcarbazole (Sigma Chemical Co., St. Louis, Missouri, USA) were used as substrate chromogen. Sections were counterstained in Mayer's hematoxylin. Liver glycogen content was determined by periodic acid-Schiff staining of paraffin sections.

Morphometric analysis. Pancreases were obtained from 4-month-old control and transgenic mice, and immunohistochemical detection of insulin was performed in 3 sections $(2-3 \mu \mathrm{m})$ separated by $200 \mu \mathrm{m}$. The islet area $\left(\mathrm{mm}^{2}\right)$ and the area of each section were determined with an image analyzer (QUE-2; Olympus Optical Co., Tokyo, Japan). The percentage of $\beta$-cell area in the pancreas was calculated by dividing the area of all insulin-positive cells in 1 section by the total area of this section and multiplying this ratio by 100 . The islet mass was calculated by multiplying the pancreas weight by the percentage of islet area. The $\beta$-cell mass was calculated by multiplying islet mass by the percentage of $\beta$ cells per islet. The percentage of cells that were positive for antibodies to insulin, glucagon, or somatostatin was determined in 20 islets from 5 transgenic mice and 5 control mice.

Determination of insulin secretion and glucose utilization. Islets were obtained from the pancreas by digestion with collagenase P (Roche Molecular Biochemicals) (27). Islets were collected by hand picking under a dissection microscope. Insulin secretion was determined as described by Valera et al. (24). Glucose utilization was measured as the conversion of $\mathrm{D}-\left[5-{ }^{3} \mathrm{H}\right]$ glucose into tritiated water, using batches of 30 islets and 2-hour incubations at $37^{\circ} \mathrm{C}$ in Krebs-Ringer medium containing $\mathrm{D}-\left[5-{ }^{3} \mathrm{H}\right]$ glucose at a final concentration of $2.8 \mathrm{mM}$, $5.5 \mathrm{mM}$, or $16.7 \mathrm{mM}$ (28). Cell metabolism was stopped by the addition of $25 \mu \mathrm{L}$ of $0.2 \mathrm{~N} \mathrm{HCl}$. Tritiated water was measured by liquid scintillation counting.

Hormone and metabolite assays. The levels of serum insulin, C-peptide, and IGF-II, and the concentration of plasma glucagon were determined by radioimmunoassay (RIA). Insulin was measured using an insulin assay kit from CIS Biointernational (Gif-Sur-Yvette Cedex, France). The assay kits for C-peptide and glucagon came from Linco Research Inc. (St. Charles, Missouri, USA). IGF-II was measured with the PreRIA Pack from GroPep Pty Ltd. IGF-II assay was performed with [125I]IGF-II from Amersham Pharmacia Biotech (Uppsala, Sweden). To determine proinsulin processing, HPLC was performed on acid-ethanol extracts of islets obtained from fed control and transgenic mice. The samples were loaded on a reverse-phase C18 column (micro-Bondapak; Waters Corp., Milford, Massachusetts, USA), protected by a precolumn of $\mathrm{C} 18 /$ Corasil and equilibrated 
with $0.1 \%$ trifluoroacetic acid ( $\mathrm{pH} 2.0)$. Samples were eluted with a linear gradient of $20-50 \%$ acetonitrile for 30 minutes at a flow rate of $1.5 \mathrm{~mL} / \mathrm{min}$. Fractions were collected every 30 seconds for 10 minutes. These fractions were lyophilized and resolved in $100 \mu \mathrm{L}$ of $0.1 \mathrm{M}$ borate buffer ( $\mathrm{pH}$ 8.6) containing 0.5\% BSA. Samples were then analyzed by RIA. The HPLC system was standardized using a mixture containing $5 \times 10^{-4} \mathrm{M}$ porcine insulin and $5 \times 10^{-5} \mathrm{M}$ human recombinant proinsulin (Sigma Chemical Co.). Glucose was measured in blood with a Glucometer Elite analyzer (Bayer Corp., Tarrytown, New York, USA). Serum triglycerides were determined enzymatically using GPO-PAP (Boehringer Mannheim $\mathrm{GmbH}$ ). Serum FFAs were measured by the acyl-CoA synthase and acyl-CoA oxidase method (Wako Chemicals GmbH, Neuss, Germany).

Statistical analysis. All values are expressed as mean \pm SEM. Statistical analysis was carried out using the Student-Newmann-Keuls test. Differences were considered statistically significant at $P<0.05$.

\section{Results}

Expression of IGF-II in pancreatic $\beta$ cells of transgenic mice. RIP-I/IGF-II chimeric gene was microinjected into mouse embryos, and 4 founder mice (C57BL6/SJL genetic background) were obtained. The studies presented below were performed in parallel using 3 lines $(1,2$, and 3$)$ of transgenic mice showing a similar phenotype. Line 1 carried about 40 intact copies of the transgene whereas lines 2 and 3 integrated only about 15 copies, as determined by Southern blot (data not shown). Transgenic mice expressed high levels of IGFII, as shown by the fact that IGF-II mRNA was detected in the pancreas of all lines of transgenic mice but not in control mice (Figure 1). No expression of the transgene was noted in liver or muscle of the transgenic mice (data not shown). After immunohistochemical analysis, no IGF-II signal was observed in islets from either 3-day-old (data not shown) or 4-month-old control mice (Figure 2a), whereas high levels of IGF-II were detected in islets from transgenic mice of the same age (Figure 2d). Although IGF-II immunoreactivity has been detected in insulin-producing cells of healthy rats and humans $(7,8)$, no IGF-II immunostaining was noted in islets from control mice. This may be the result of the IGF-II antibody used in this study, which probably detects only high levels of IGF-II. This is also consistent with the fact that IGF-II mRNA was noted only in pancreases from transgenic mice. Furthermore, transgenic mice showed higher levels (about 2 -fold) of IGF-II in serum than did controls $(26 \pm 8 \mathrm{ng} / \mathrm{mL}$ vs. 12 $\pm 5 \mathrm{ng} / \mathrm{mL}$ ). Moreover, pancreases of transgenic mice had higher levels (about 2-fold) of insulin mRNA than did pancreases of control mice (Figure 1), suggesting that IGF-II overexpression led to increased $\beta$-cell mass or insulin gene expression, or both. Nevertheless, a small induction of proinsulin gene transcription by IGF-II has been reported in HIT insulinoma cells (29). Expression of IGF-II in islets led to morphological changes. Islets

\section{Table 1}

Morphometric analysis of pancreas

$\begin{array}{lcc} & \text { Control } & \text { Transgenic } \\ \text { \% Islet area / Pancreas area } & 0.52 \pm 0.08 & 1.3 \pm 0.10 \\ \text { \% beta cells / Islet } & 75 \pm 3.0 & 72 \pm 5.0 \\ \text { \% alpha cells / Islet } & 20 \pm 1.4 & 22 \pm 2.5 \\ \text { \% delta cells / Islet } & 5 \pm 0.4 & 6 \pm 1.3 \\ \text { Pancreas weight (mg) } & 121.4 \pm 12 & 157.0 \pm 4 \\ \text { Islet cell mass (mg) } & 0.63 & 2.04 \\ \text { Beta cell mass (mg) } & 0.47 & 1.47\end{array}$

Five transgenic and 5 normal pancreases were analyzed as described in Methods.

from transgenic mice showed high levels of insulin immunoreactivity (Figure 2e and Figure 3, b and d). However, most of the islets from transgenic mice had altered morphology (Figures 2 and 3). These islets were larger than those in controls and showed a more elongated, irregular shape. This effect was already evident in the pancreas of 3-day-old transgenic mice (Figure 3, a and b), suggesting that IGF-II overexpression led to $\beta$-cell hyperplasia. Similarly, prediabetic, insulin-resistant ZDF rats show enlarged islets $(30,31)$. In addition, an abnormal distribution of insulin-producing cells was also noted in islets from transgenic mice - several cells from the islet core, where $\beta$ cells are located, were not stained (Figure 2, b and e). Moreover, in contrast to islets from control mice, which showed normal distribution of $\alpha$ cells at the periphery of the islet, islets from transgenic animals had glucagon-producing cells randomly distributed throughout the islet core (Figure 2, c and f). Similar morphological alterations are also observed in animal models of type 2 diabetes and obesity, like ZDF rats or $o b / o b$ and $d b / d b$ mice (32-34).

Quantitative morphometric analysis was performed to determine whether there was an increase in $\beta$-cell mass. The islet mass and $\beta$-cell mass per unit of exocrine pancreatic area were about 3 -fold higher in transgenic mice than in control mice (Table 1; Figure 3, $\mathrm{c}$ and d). Although 4-month-old transgenic mice had body weight similar to that of controls $(25.1 \pm 0.9 \mathrm{~g}$ and $25.0 \pm 0.5 \mathrm{~g}$, respectively), an increase in pancreas weight was noted (Table 1). No significant differences were found in the weight of other organs (data not shown). Because islet

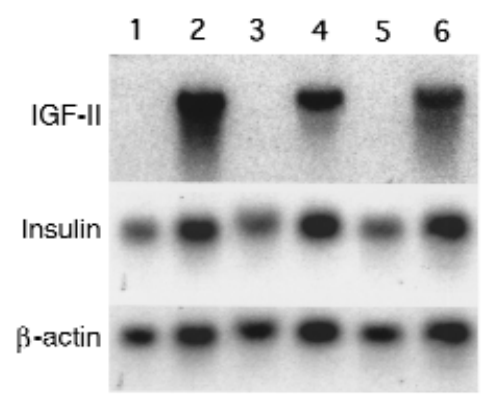

\section{Figure 1}

Expression of IGF-II in the pancreas. Total cellular RNA was obtained from control mice and 3 lines of transgenic mice (1,2, and 3), as indicated in Methods. After transfer, membranes were tested for IGFII and insulin. Lanes 1, 3, and 5: control mice. Lanes 2, 4, and 6: transgenic mice from lines 1,2 , and 3 , respectively. 
Table 2

Serum parameters

\begin{tabular}{lcccc}
\hline & $\begin{array}{c}\text { Glucose } \\
(\mathrm{mg} / \mathrm{dL})\end{array}$ & $\begin{array}{c}\text { Insulin } \\
(\mathrm{ng} / \mathrm{dL})\end{array}$ & $\begin{array}{c}\text { Triglycerides } \\
(\mathrm{mg} / \mathrm{dL})\end{array}$ & $\begin{array}{c}\mathrm{FFAs} \\
(\mathrm{mmol} / \mathrm{L})\end{array}$ \\
$\begin{array}{lcccc}1 \text { month } \\
\text { Control }\end{array}$ & $150 \pm 11$ & $1.5 \pm 0.3$ & - & - \\
$\begin{array}{l}\text { Transgenic } \\
4 \text { months }\end{array}$ & $166 \pm 7$ & $5.0 \pm 1.0$ & - & - \\
$\begin{array}{l}\text { Control } \\
\text { Transgenic }\end{array}$ & $150 \pm 6$ & $1.9 \pm 0.2$ & $121 \pm 9$ & $0.80 \pm 0.05$ \\
& $213 \pm 12$ & $5.5 \pm 0.5$ & $154 \pm 9$ & $0.97 \pm 0.04$
\end{tabular}

Serum parameters from 1-month-old and 4-month-old fed control and transgenic mice were determined as described in Methods. Results are mean \pm SEM of at least 15 animals in each group.

cells contain type 1 IGF receptors $(29,35,36)$, these results suggest that the IGF-II produced by the $\beta$ cells probably acted in a paracrine/autocrine manner within the islets. However, similar percentages of insulin-, glucagon-, or somatostatin-producing cells per islet were found in control and transgenic islets (Table 1). Therefore, these findings suggest that overexpression of IGFII in $\beta$ cells led to induction of islet hyperplasia. This was already detected in 3-day-old transgenic mice (Figure 3, $a$ and $b$ ), indicating that these mice had higher $\beta$-cell mass than did controls very early in life, which probably led to increased insulin release.

Transgenic mice expressing IGF-II showed altered $\beta$-cell function. To discern whether these mice also showed alterations in $\beta$-cell function, glucose-stimulated insulin secretion was next analyzed in islets obtained from control and transgenic mice about 4 months old. At $2.8 \mathrm{mM}$ and $5.5 \mathrm{mM}$ glucose concentrations, the release of insulin from islets of normal mice was low, but $11.1 \mathrm{mM}$ and $16.7 \mathrm{mM}$ glucose induced insulin secretion. Islets from transgenic mice secreted more insulin than did those from control mice at each glucose concentration tested (Figure 4a). Because glucose must be metabolized to induce insulin secretion, glucose utilization through glycolysis was measured. At all glucose concentrations studied, the rate of glucose use in islets expressing IGF-II was higher than in islets from nontransgenic mice (Figure 4b). Similarly, islets of prediabetic ZDF rats secreted significantly more insulin over a wide range of glucose concentrations, resulting in a leftward shift in the dose-response curve relating glucose concentration and insulin secretion (30).

Insulin and proinsulin content were also determined in islets. After HPLC analysis of islet extracts and
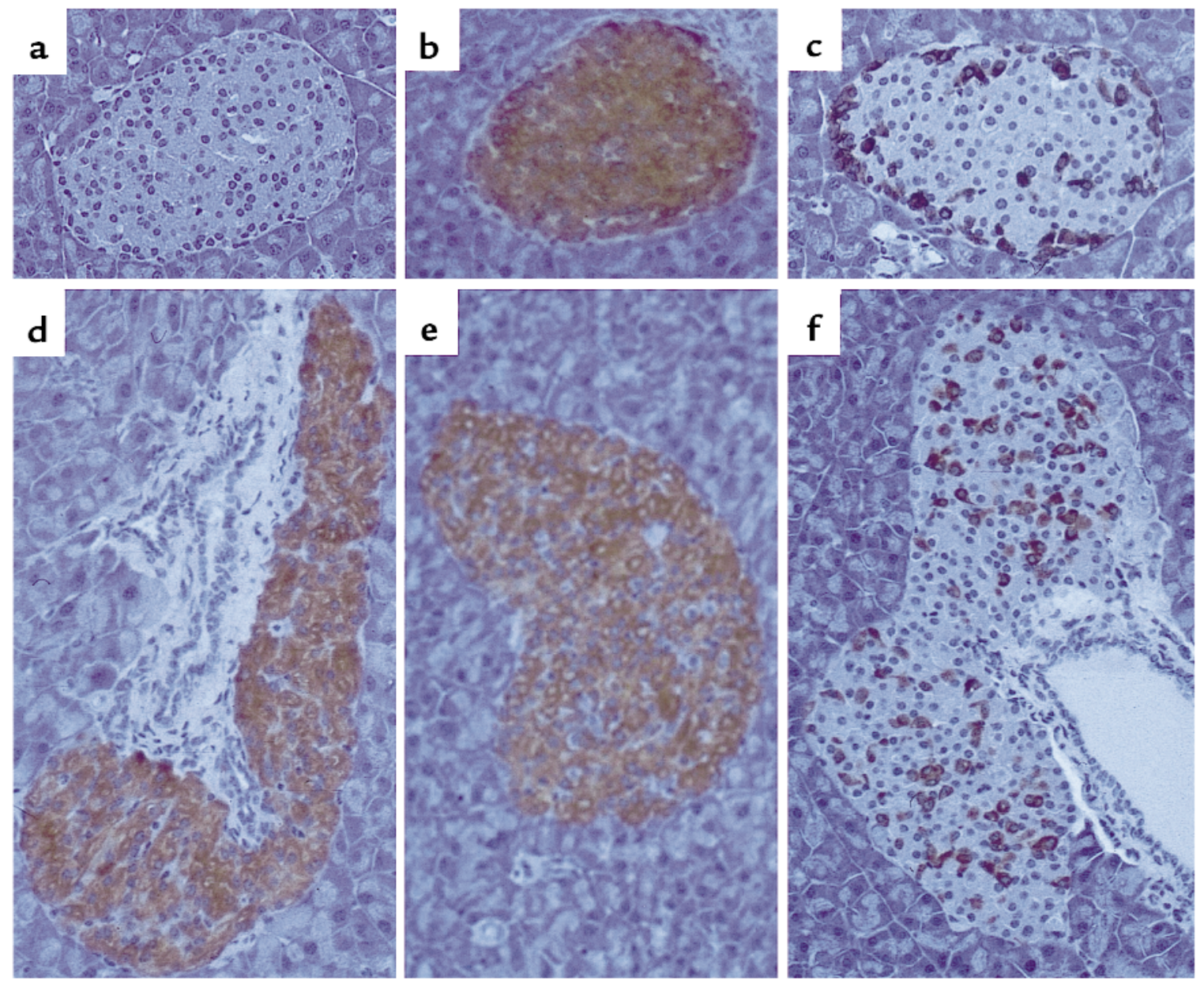

Figure 2

Representative sections of pancreas from 4-month-old control (a-c) and transgenic mice ( $\mathbf{d}-\mathbf{f})$ showing staining of IGF-II (a and $\mathbf{d})$, insulin (b and $\mathbf{e})$, and glucagon (c and $\mathbf{f}) . \times 400$. 
radioimmunoassay of each fraction, only 2 peaks were identified, corresponding to insulin and proinsulin according to their elution times. Insulin was the major component in the extracts of both control and transgenic islets, and its concentration was about $70 \%$ higher in islets from transgenic mice than in those from control mice (104 $\pm 26 \mathrm{fmol} /$ islet vs. $61 \pm 3 \mathrm{fmol} /$ islet). Proinsulin levels in transgenic islets were 6-fold those in control islets $(9.1 \pm 1.4 \mathrm{fmol} /$ islet vs. $1.5 \pm 0.1$ $\mathrm{fmol} /$ islet). Nevertheless, insulin concentration in transgenic islets was about 10 -fold higher than proinsulin content, indicating that islets from transgenic mice processed proinsulin to mature insulin.

Transgenic mice expressing IGF-II develop byperinsulinemia and insulin resistance. One-month-old fed transgenic mice had blood insulin levels that were about 3-fold those of control mice (Table 2). However, these mice were normoglycemic (Table 2). Similarly, older (more than 3 months old) fed transgenic mice were hyperinsulinemic, but showed an increase in blood glucose levels (Table 2). Furthermore, the 3-month-old transgenic mice had levels of circulating C-peptide that were 2.3 times as high as those of the controls ( $995 \pm 15 \mathrm{pM}$ vs. $433 \pm 12 \mathrm{pM}$ ), suggesting that processed insulin rather than proinsulin had increased. In addition, transgenic animals also showed a slight increase in serum concentration of triglycerides and FFAs (Table 2). Nevertheless, similar plasma glucagon levels were detected in transgenic and control mice $(126 \pm 21 \mathrm{pg} / \mathrm{mL}$ and $136 \pm 12 \mathrm{pg} / \mathrm{mL}$, respectively).

An intraperitoneal glucose tolerance test was also performed in starved (24 hours) 4-month-old mice. In contrast to control mice, the high levels of blood glucose found in transgenic mice did not return to basal values 180 minutes after intraperitoneal injection of glucose (Figure 5a). These results indicate that transgenic mice were glucose intolerant. Moreover, when an intraperitoneal insulin tolerance test (injection of $0.75 \mathrm{IU} / \mathrm{kg}$ body weight of soluble insulin [Humulin Regular; Eli Lilly \& Co., Indianapolis, Indiana, USA]) was performed in 6month-old fed mice, a significantly reduced hypoglycemic response was observed in transgenic mice compared with control mice. Thus, by 60 minutes, whereas control mice showed a $65 \%$ decrease in blood glucose levels, transgenic mice had only a $25 \%$ decrease of glycemia (Figure $5 \mathrm{~b}$ ). All these results suggest that transgenic mice

Table 3

Serum parameters after a high fat diet

\begin{tabular}{lccc}
\hline & $\begin{array}{c}\text { Glucose } \\
(\mathrm{mg} / \mathrm{dL})\end{array}$ & $\begin{array}{c}\text { Insulin } \\
(\mathrm{ng} / \mathrm{dL})\end{array}$ & $\begin{array}{c}\text { body weight } \\
(\mathrm{g})\end{array}$ \\
$\begin{array}{lccc}\text { Standard diet } \\
\text { Control }\end{array}$ & & & \\
$\quad$ Transgenic & $150 \pm 5$ & $3.1 \pm 0.3$ & $30.2 \pm 1.4$ \\
High fat diet & $200 \pm 7$ & $10.3 \pm 0.5$ & $31.5 \pm 2.3$ \\
$\quad$ Control & & & \\
$\quad$ Transgenic & $160 \pm 10$ & $11.7 \pm 1.7$ & $40.3 \pm 4.2$ \\
& $210 \pm 7$ & $28.0 \pm 3.5$ & $40.5 \pm 2.7$
\end{tabular}

Serum parameters after a high-fat diet. Control and transgenic mice were fed a high-fat diet for 2 months, after which serum parameters were determined as described in Methods. Results are mean \pm SEM of at least 8 animals in each group.

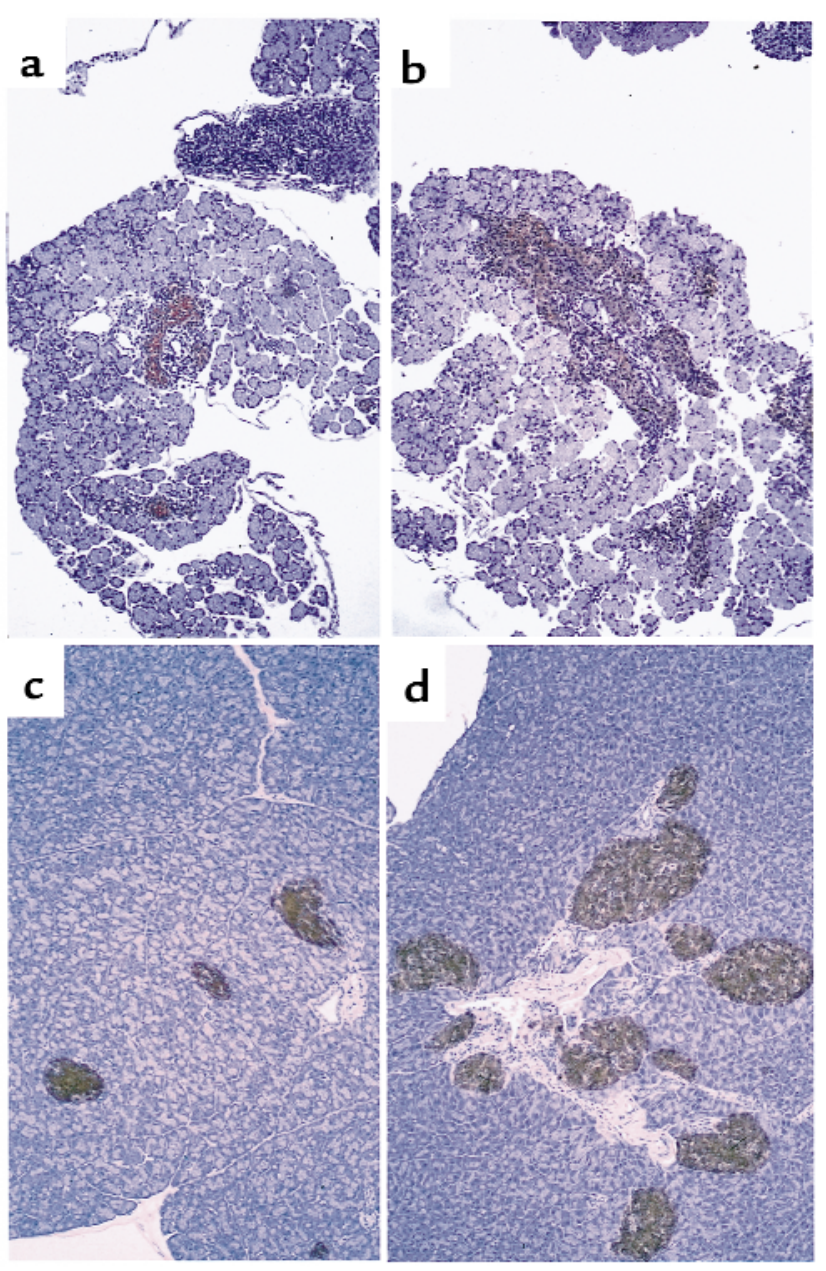

Figure 3

Immunohistochemical analysis of insulin expression in islets from 3day-old ( $\mathbf{a}$ and $\mathbf{b}$ ) and 4-month-old ( $\mathbf{c}$ and $\mathbf{d}$ ) control and transgenic mice. Pancreas from control mice (a and $\mathbf{c}$ ), and pancreas from transgenic mice ( $\mathbf{b}$ and $\mathbf{d}$ ), stained for insulin ( $\mathbf{a}$ and $\mathbf{b}),(\times 400)$; and (c and d), ( $\times 200)$. Note that transgenic mice appear to have an increased number of enlarged islets.

expressing IGF-II develop mild type 2 diabetes.

Feeding transgenic mice a high-fat diet may lead to overt diabetes. To determine whether a high-fat diet exacerbated the diabetic phenotype, 6-month-old transgenic mice overexpressing IGF-II were fed a high-fat diet for up to 2 months. After $6-8$ weeks on this diet, about $30 \%$ (4 of 12) of the transgenic mice developed overt diabetes with severe hyperglycemia (> $500 \mathrm{mg} / \mathrm{dL}$ ) and lost about $25 \%$ of their body weight. The remaining transgenic mice ( 8 of 12) were mildly hyperglycemic, but they developed higher hyperinsulinemia (Table 3 ) that was about 9-fold that of control mice fed a standard diet (Table 3). Similarly, when fed a high-fat diet for 2 months, control mice did not show any increase in glycemia (Table 3). However, a high increase (about 3.7-fold) in insulinemia was also noted in these mice (Table 3). Both control and transgenic mice showed a similar increase (about 30\%) in body weight gain (Table 3). In addition, control mice and transgenic mice had similar food intake (about 4.5 


\section{a}

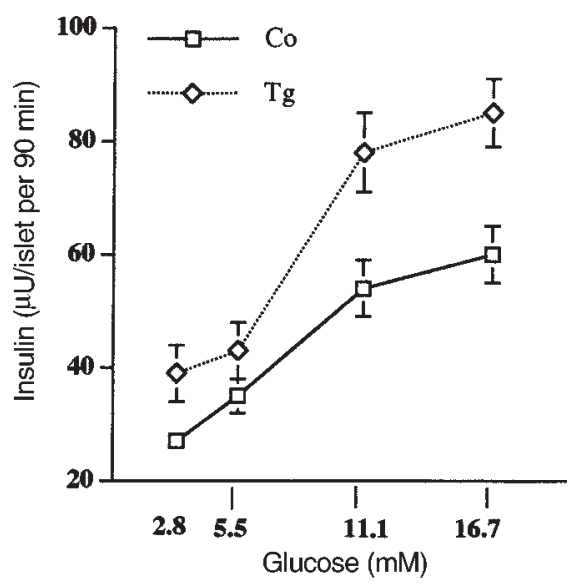

b

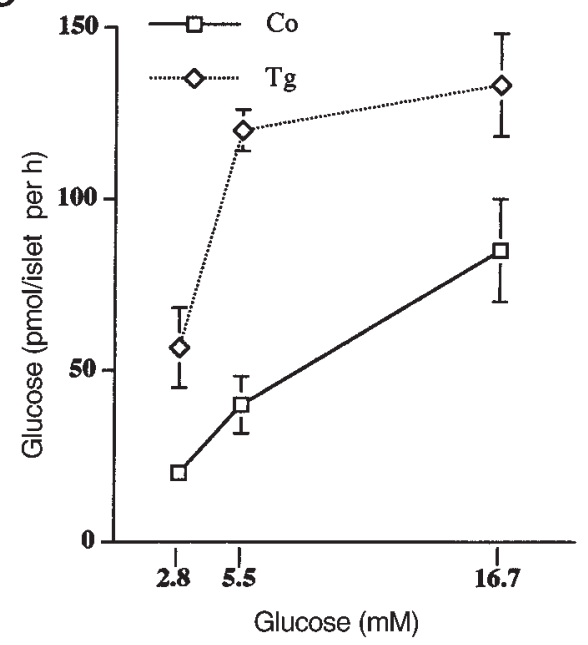

Figure 4

(a) Glucose-induced insulin secretion by isolated islets. Insulin secretion at $2.8 \mathrm{mM}, 5.5 \mathrm{mM}, 11.1 \mathrm{mM}$ and $16.7 \mathrm{mM}$ glucose was determined as indicated in Methods, in islets isolated from control and transgenic mice. Results are the mean \pm SEM of 8 animals in each group. (b) Glucose utilization by pancreatic $\beta$ cells. Islets were incubated in the presence of different glucose concentrations and the utilization of the sugar was determined by measuring the formation of $\left[{ }^{3} \mathrm{H}\right]_{2} \mathrm{O}$ from $\mathrm{D}-\left[5^{-}{ }^{3} \mathrm{H}\right]$ glucose. Results are the mean $\pm \mathrm{SEM}$ of 3 independent experiments performed in triplicate. Co, control mice; $\mathrm{Tg}$, transgenic mice.

$\pm 0.4 \mathrm{~g} /$ day on the standard diet and $4.0 \pm 0.4 \mathrm{~g} /$ day on the high-fat diet). These results suggest that in an islet hyperplastic model such as transgenic mice overexpressing IGF-II, an increase in circulating lipids might trigger the process that leads to overt diabetes.

Influence of genetic background in IGF-II-mediated diabetic alterations. Transgenic mice aged 8 months and older, expressing IGF-II in $\beta$ cells, were insulin-resistant but had body weight similar to controls (Table 3 ). Because the genetic background plays a key role in the development of type 2 diabetes and obesity (37), transgenic mice (of C57BL6/SJL background) were backcrossed to C57KsJ mice. The $\mathrm{N} 1$ generation of transgenic mice $(50 \% \mathrm{C} 57 \mathrm{KsJ}$ background) overexpressing IGF-II was obtained to assess whether overexpression of IGF-II in a C57KsJ genetic background led to insulin resistance and obesity. Six-month-old fed N1 transgenic mice were hyperinsulinemic and hyperglycemic, and showed a slight increase in serum triglycerides and FFA concentrations (Table 4). Six-month-old N1 C57KsJ transgenic mice also showed altered glucose-tolerance tests (Figure 6a). Furthermore, after intraperitoneal injection of glucose, the blood glucose levels in these transgenic mice (Figure 6a) were even higher than those noted in C57BL6/SJL transgenic mice (Figure 5a). In addition, $\mathrm{N} 1$ transgenic mice had higher body weight than $\mathrm{N} 1$ control mice (Figure $6 \mathrm{~b}$ ). Although a

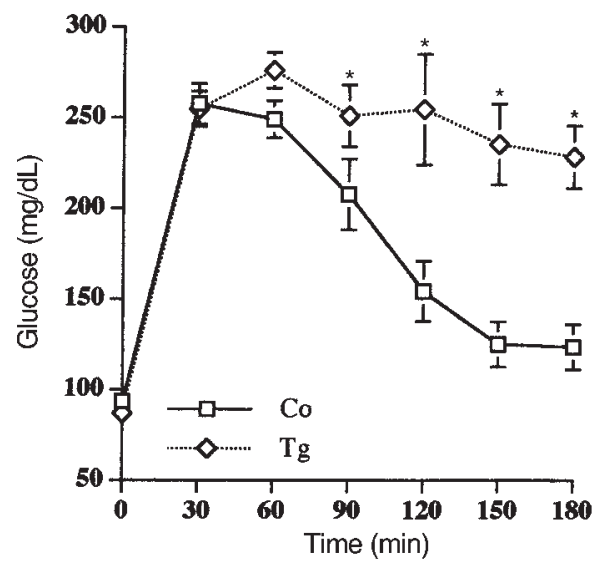

b

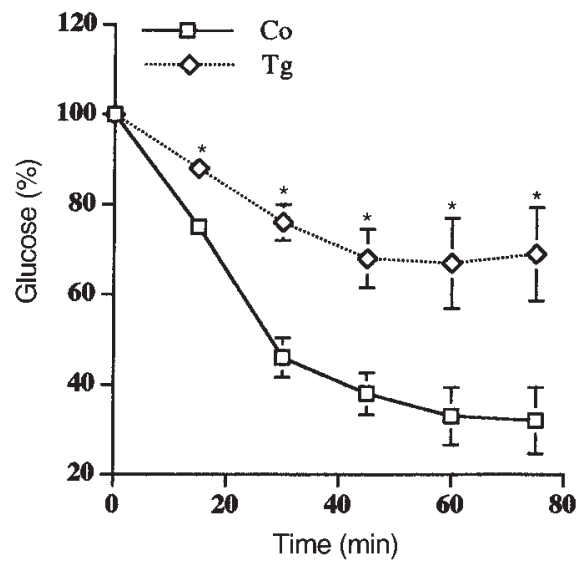

\section{Figure 5}

Intraperitoneal glucose and insulin tolerance tests. (a) Glucose tolerance test. Overnight-starved mice were given an intraperitoneal injection of glucose $(1 \mathrm{mg} / \mathrm{g}$ body wt). Blood samples were taken at the times indicated from the tail vein of the same animals. Glucose was measured as indicated in Methods. Results are mean \pm SEM of 12 transgenic and 12 control mice. (b) Insulin tolerance test. Awake fed control and transgenic mice were injected intraperitoneally with $0.75 \mathrm{IU}$ of a soluble insulin. Blood samples were taken from the tail vein of the same animals at the times indicated, and glucose concentration was determined as indicated in Methods. Results are mean \pm SEM of 8 transgenic and 8 control mice. ${ }^{*} P<0.05$ vs. control. 
$\mathbf{a}$

Figure 6

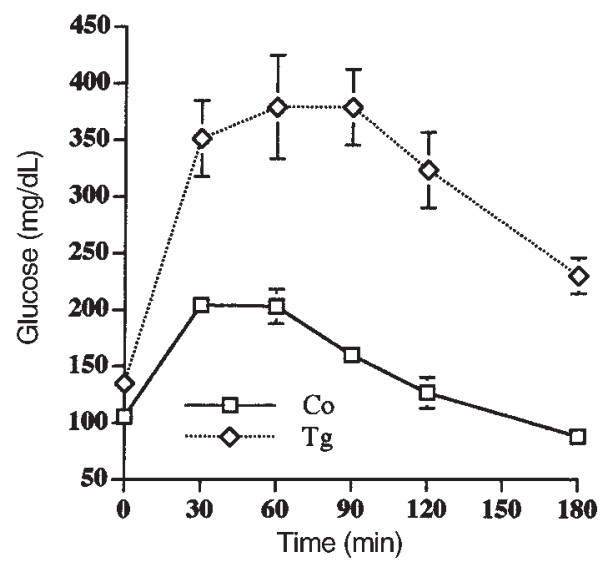

b

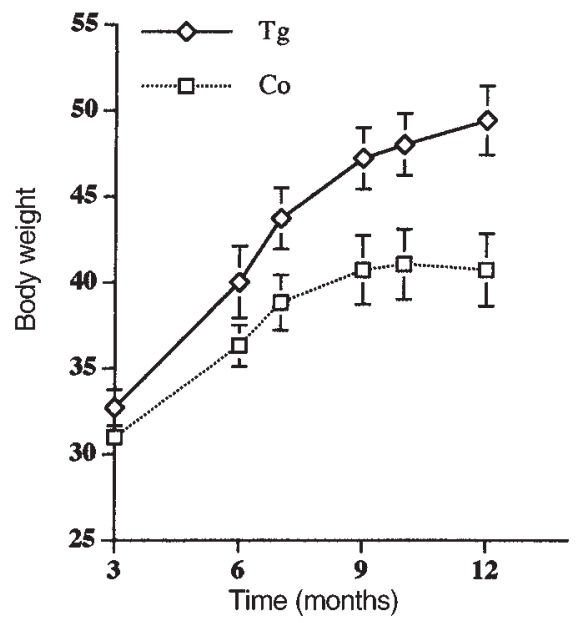

Intraperitoneal glucose tolerance test and body weight in N1 C57Ks) transgenic mice. (a) Glucose tolerance test. Six-month-old mice starved for 24 hours were given an intraperitoneal injection of glucose $(1 \mathrm{mg} / \mathrm{g}$ body wt). Blood samples were taken at the times indicated from the tail vein of the same animals. Glucose was measured as indicated in Methods. Results are mean \pm SEM of 10 transgenic and 10 control mice. (b) Changes in body weight of control mice and transgenic mice. Data are mean \pm SEM of 12 mice in each group.

3-month-old N1 C57KsJ control and transgenic mice had similar body weight, 12-month-old transgenic mice showed about a $60 \%$ increase in body weight compared with only about $27 \%$ gained by controls (Figure 6b). Thus, N1 C57KsJ transgenic mice overexpressing IGF-II in $\beta$ cells developed obesity.

Histological analysis of pancreases of $\mathrm{N} 1$ transgenic mice showed high islet hyperplasia and altered islet structure, with $\alpha$ cells randomly distributed in the core (Figure 7, a-d), similar to the situation observed in C57BL6/SJL transgenic mice. Moreover, on analysis of sections stained with periodic acid-Schiff, the liver of fed 12-month-old N1 transgenic mice showed massive vacuolization due to fat deposition and lack of glycogen storage (Figure 7f). In contrast, the livers of N1 control mice had normal morphology and accumulated glycogen (Figure 7e). Similarly, no alterations in hepatic morphology were detected in either C57BL6/SJL control or transgenic mice aged 4-8 months (data not shown). The development of fatty liver is a feature also detected in animal models of type 2 diabetes and obesity. Thus, these results suggest that the presence of 50\% C57KsJ genetic background in the transgenic mice overexpressing IGF-II in $\beta$ cells exacerbates diabetic alterations.

\section{Discussion}

Our results show that increased expression of IGF-II in $\beta$ cells of transgenic mice led to hyperplasia and morphological alterations of islets. Similar changes are observed in animal models of type 2 diabetes and obesity, such as prediabetic ZDF rats or $o b / o b$ and $d b / d b$ mice (30-34), which show enlarged islets with deorganized intra-islet cell distribution. Therefore, the alterations found in our transgenic mice may result from a direct effect of IGF-II on $\beta$-cell proliferation, or a compensatory response resulting from the insulin resistance noted in these mice, or both. Insulin-resistant mice that are heterozygous for null alleles in both the insulin receptor and insulin receptor substrate- 1 (Ir ${ }^{+/} /$Irs-1 ${ }^{+/}$) exhibit $\beta$-cell hyperplasia and altered $\alpha$-cell distribution throughout the islet (38). In these double-heterozygous mice, there is no $\beta$-cell hyperplasia at 1 month of age. Therefore it has been suggested (38) that there must be a $\beta$-cell growth factor that stimulates the massive $\beta$-cell proliferation in young animals. Although glucose stimulates $\beta$-cell growth (39), Bruning et al. indicate that the growth factor is probably not glucose, because a significant degree of islet cell hyperplasia can be detected in normoglycemic $\mathrm{Ir}^{+/-} / \mathrm{Irs}-1^{+/-}$mice (38). Similarly, homozygous Irs-1-deficient mice (Irs-1-/-) are normoglycemic and hyperinsulinemic, and show islet hyperplasia $(38,40-42)$. In contrast, homozygous Irs-2-deficient mice $(36,42)$, along with mice that are both heterozygous for null alleles of Irs- 1 and homozygous for null alleles of Irs-2 (Irs-1//-/Irs-2-/-) (36), and mice that are both heterozygous for null alleles of IGF-I receptor (Igf1r) and homozygous for null alleles of Irs-2 $\left(\right.$ Igfl $r^{+/-} /$Irs-2-/-) (36) show marked reduction of $\beta$-cell mass and die from diabetes due to $\beta$-cell insufficiency. These studies suggest that IGF-I receptors couple to Irs2 in the pancreatic islet to mediate $\beta$-cell development, proliferation, and survival (36). It has been postulated that the mitogenic signaling of IGF-II is mediated by the type 1 IGF receptor (IGF1R) $(43,44)$, and that the

\section{Table 4}

Serum parameters $\mathrm{C} 57 \mathrm{Ks}$, N 1

\begin{tabular}{llccc}
\hline & $\begin{array}{c}\text { Glucose } \\
(\mathrm{mg} / \mathrm{dL})\end{array}$ & $\begin{array}{c}\text { Insulin } \\
(\mathrm{ng} / \mathrm{dL})\end{array}$ & $\begin{array}{c}\text { Triglycerides } \\
(\mathrm{mg} / \mathrm{dL})\end{array}$ & $\begin{array}{c}\mathrm{FFAs} \\
(\mathrm{mmol} / \mathrm{L})\end{array}$ \\
Control & $156 \pm 10$ & $1.6 \pm 0.5$ & $105 \pm 11$ & $0.66 \pm 0.08$ \\
Transgenic & $241 \pm 9$ & $3.7 \pm 0.5$ & $118 \pm 2$ & $0.74 \pm 0.06$
\end{tabular}

Serum parameters from 12-month-old N1 C57KsJ control and transgenic mice were determined as described in Methods. Results are mean \pm SEM of at least 12 animals in each group. 
main function of IGF-II/Man-6-P receptors is to clear IGF-II from the serum and target it for degradation in lysosomes (45-47). Thus, in transgenic mice overexpressing IGF-II in $\beta$ cells, autocrine or paracrine interaction of IGF-II with IGF-I receptors in islets would probably lead to increased $\beta$-cell proliferation and development of islet hyperplasia. Studies in fibroblasts from mouse embryos homozygous for null alleles of $I g f 1 r$ have shown that IGF-II can also stimulate cell prolifer- ation through the insulin receptor (48). In addition, $\beta$ cells contain insulin receptors, and mice lacking insulin receptor specifically in $\beta$ cells show a decrease in islet size and insulin content (49). Therefore, IGF-II produced by the $\beta$ cells of transgenic mice might also induce $\beta$-cell proliferation through the insulin receptor.

The alteration in $\alpha$-cell distribution noted in islets of transgenic mice overexpressing IGF-II may not be a general occurrence with $\beta$-cell hyperplasia, because trans-
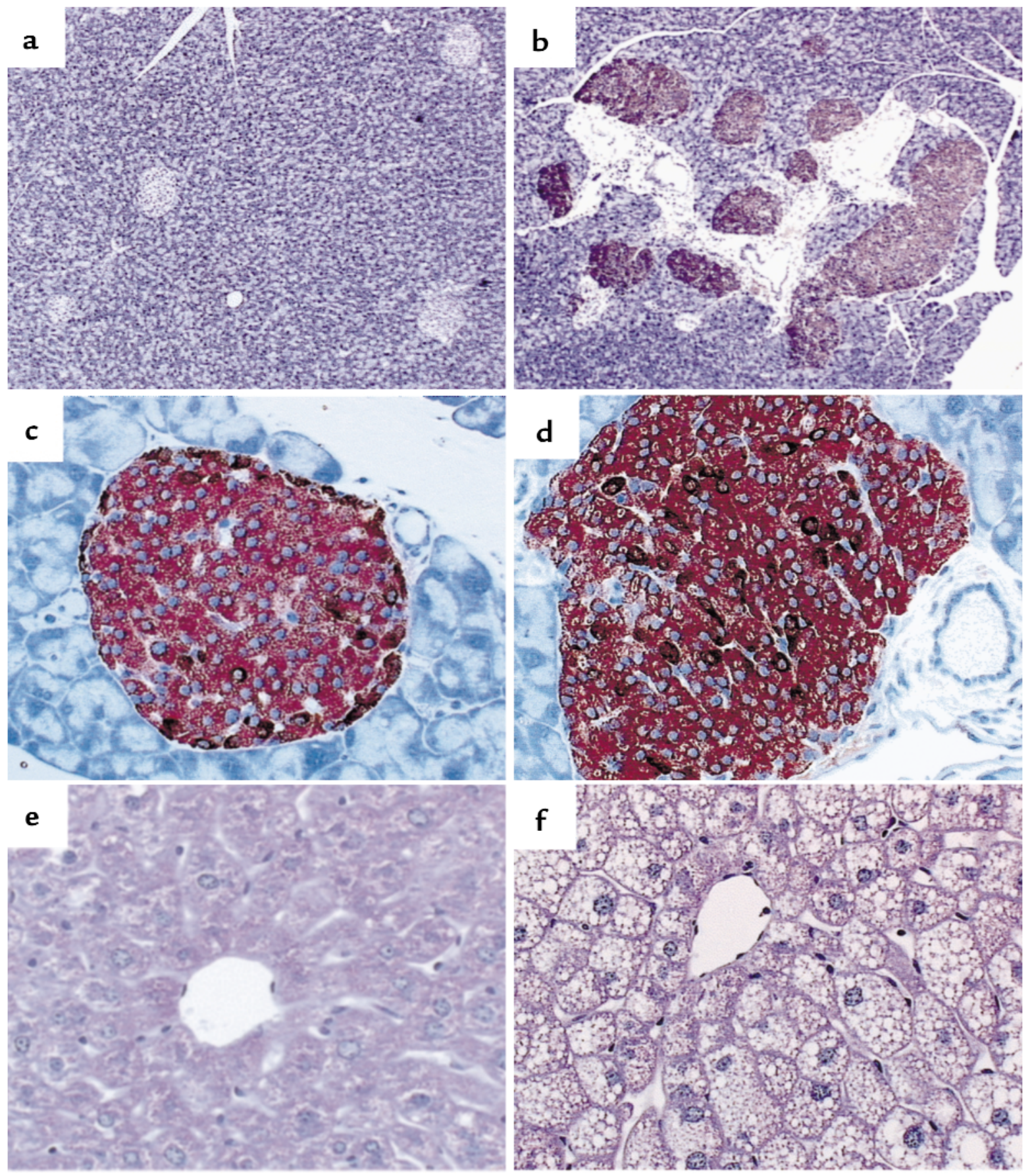

Figure 7

(a-d) Immunohistochemical analysis of IGF-II (a and b), insulin (red), and glucagon (brown) (c and d) expression in islets from 12-monthold N1 C57KsJ mice. Control mice are shown in $\mathbf{a}$ and $\mathbf{c}$; transgenic mice are shown in $\mathbf{b}$ and $\mathbf{d}$. (e and $\mathbf{f}$ ) PAS staining of the liver from control (e) and transgenic (f) mice aged 12 months. $\mathbf{a}$ and $\mathbf{b}, \times 100 ; \mathbf{c}-\mathbf{f}, \times 200$. 
genic mice overexpressing growth hormone are highly hyperinsulinemic and normoglycemic (50), and show high hyperplasia of islets but normal distribution of $\alpha$ cells (J. Visa and F. Bosch, unpublished observations). Similarly, overexpression of IGF-I in $\beta$ cells of transgenic mice led to islet hyperplasia but normal distribution of $\alpha$ cells (C. Costa and F. Bosch, unpublished observations). Thus, this study suggests that islet production of IGF-II might alter the location of islet cells and lead to islet disorganization, which is consistent with the finding that the starfish-shaped islets of GK rats show increased IGF-II expression (8). Similarly, fetuses of mouse chimeras overexpressing the mouse IGF-II gene show hyperplastic islets of irregular shape and altered morphology on day 19-20 of gestation (51).

Transgenic mice overexpressing IGF-II in $\beta$ cells were hyperinsulinemic early in life and showed altered glucose and insulin tolerance tests, consistent with the fact that these mice developed insulin resistance. In adult rodents, serum levels of IGF-II are very low, whereas high levels of IGF-II persist in humans (52). However, our transgenic mice had low levels of circulating IGF-II, and the mild diabetic phenotype observed was probably not the result of a peripheral effect of IGF-II. In contrast, transgenic mice overexpressing IGF-II in the liver $(53,54)$ show a 20 - to 30 fold increase in circulating IGF-II levels, which are similar to those observed in adult humans. However, these mice develop hypoglycemia and hypoinsulinemia, and show marked improvement in peripheral (skeletal muscle) insulin action $(53,54)$.

Islets from our IGF-II transgenic mice secrete more insulin in response to increasing glucose concentrations than do islets from control mice. Nevertheless, it has been described that in pancreas perfused in vitro with high concentrations of IGF-II, insulin release at $7.8 \mathrm{mM}$ glucose was unaffected, and only a slight suppressive effect was noted at $16.7 \mathrm{mM}$ glucose (55). Similarly, no effect on insulin release by isolated islets treated with IGF-II has been found (56). An increase in insulin secretion is also detected when glucose-stimulated insulin release is determined in islets of prediabetic ZDF rats (30). Islets from these animals secrete high levels of insulin, resulting in a leftward shift in the dose-response curve relating glucose concentration and insulin production (30). Thus, our results indicate that islets from transgenic mice chronically producing IGF-II have an altered function, as in the prediabetic state.

Culture of fetal islets with increasing concentrations of glucose and amino acids is associated with both a significant increase in the release of endogenous IGFII and stimulation of DNA synthesis (5). An increase in IGF-II might result from effects of nutrients on $\beta$ cells. Therefore, it may be hypothesized that the mitogenic effects of glucose, amino acids, or lipids on islets were mediated by paracrine action of a growth factor such as IGF-II. Furthermore, it has been suggested that lipids play a key role in the development of type
2 diabetes $(12,57)$. In obese prediabetic ZDF rats, the increase in plasma FFAs is postulated to cause both the insulin resistance and the hyperinsulinemia of the prediabetic state $(12,57)$. A rise in plasma FFAs is associated with an increase in islet triglyceride content, which coincides with the onset of islet dysfunction and overt diabetes (58). In addition, hyperinsulinemia at low glucose concentrations, hyperplasia, and the increase in the low- $K_{\mathrm{m}}$ glucose metabolism can all be induced in normal islets by high concentrations of the long-chain FFAs that occur in obesity (59). In our study, feeding a high-fat diet increased insulin resistance and also led to overt diabetes in the IGF-II-overexpressing mice, suggesting that an increase in circulating lipids may also exacerbate the prediabetic phenotype in these mice.

Previous reports indicate that genetic background is also key in the development of diabetes and obesity (37). Thus, the physiologic impairment caused by mutation of the $o b$ gene is strongly affected by the genetic background of mice bearing this mutation (10). When the mutation is present in an inbred strain of $o b / o b$ mice designated C57BL6, the animals become insulin resistant and hyperinsulinemic, but maintain either normal or mildly elevated glucose levels. However, when the mutation is present in the C57KsJ strain, the animals become obese, insulin resistant, and overtly diabetic (10). We have also found that when the transgene was expressed in a $50 \%$ C57KsJ genetic background, transgenic mice were hyperinsulinemic and insulin resistant, but they also developed fatty liver and obesity.

Therefore, our results suggest that islet hyperplasia was an early event in the transgenic mice overexpressing IGF-II that led to hyperinsulinemia. Because tissues were exposed to sustained hyperinsulinemia, insulin resistance developed, probably through downregulation of insulin receptor number and function or post-receptor pathways, causing hyperglycemia, which may further increase insulin secretion. Therefore, the studies performed in this animal model support the hypothesis, suggested by several observations in human patients $(13,14,18-20)$ and in several animal models of type 2 diabetes $(15-17,21,23)$, that hyperinsulinemia may also be an initial event in this disease, and that insulin resistance may be a consequence of the increased insulinemia. In addition, these transgenic mice may be a suitable model in which to study the processes that lead to type 2 diabetes.

\section{Acknowledgments}

We thank R. Casamitjana for insulin measurements, and C.H. Ros, M. Moya, and A. Vilalta for technical assistance. J.C. Devedjian and J. L.Gros were recipients of postdoctoral fellowships from the Training and Mobility Program of the European Community, and J. Visa from Direcció General de Recerca (1997SGR 00110). This study was supported by grants from Fondo Investigación Sanitaria (95/1758 and 98/1063) and Fundación Ramón Areces, Spain. 
1. LeRoith, D. 1991. Insulin-like growth factors: molecular and cellular aspects. CRC Press. Boca Raton, FL. 88-110.

2. Schofield, P.N. 1992. The insulin-like growth factors: structure and biological function. Oxford University Press. Oxford, United Kingdom. 12-44.

3. Le Roith, D. 1997. Insulin-like growth factors. N. Engl. J. Med. 336:633-640.

4. Han, V.K., Lund, P.K., Lee, D.C., and D'Ercole, A.J. 1988. Expression of somatomedin/insulin-like growth factor messenger ribonucleic acids in the human fetus: identification, characterization, and tissue distribution. J. Clin. Endocrinol. Metab. 66:422-429.

5. Hogg, J., Han, V.K.M., Clemmons, D.R., and Hill, D.J. 1993. Interactions of nutrients, insulin-like growth factors (IGFs) and IGF-binding proteins in the regulation of DNA synthesis by isolated fetal rat islets of Langerhans. J. Endocrinol. 138:401-412.

6. Rabinovitch, A., Quigley, C., Russell, T., Patel, Y., and Mintz, D.H. 1982. Insulin and multiplication stimulating activity (an insulin-like growth factor) stimulate islet beta-cell replication in neonatal rat pancreatic monolayer cultures. Diabetes. 31:160-164.

7. Maake, C., and Reinecke, M. 1993. Immunohistochemical localization of insulin-like growth factor 1 and 2 in the endocrine pancreas of rat, dog, and man, and their coexistence with classical islet hormones. Cell Tissue Res. 273:249-259.

8. Hoog, A., et al. 1996. Increased amounts of a high molecular weight insulinlike growth factor II (IGF-II) peptide and IGF-II messenger ribonucleic acid in pancreatic islets of diabetic Goto-Kakizaki rats. Endocrinology. 137:2415-2423.

9. Hoog, A., et al. 1997. Ultrastructural localization of insulin-like growth factor-2 (IGF-2) to the secretory granules of insulin cells: a study in normal and diabetic (GK) rats. Ultrastruct. Pathol. 21:457-466.

10. Polonsky, K.S., Sturis, J., and Bell, G.I. 1996. Non-insulin-dependent diabetes mellitus: a genetically programmed failure of the beta cell to compensate for insulin resistance. N. Engl. J. Med. 334:777-783.

11. De Fronzo, R.A. 1997. Pathogenesis of type 2 diabetes: metabolic and molecular implications for identifying diabetic genes. Diabetes Reviews. 5:177-269.

12. McGarry, J.D. 1992. What if Minkowski had been ageusic? An alternative angle on diabetes. Science. 258:766-770.

13. Lillioja, S., et al. 1991. Exaggerated early insulin release and insulin resistance in a diabetes-prone population: a metabolic comparison of Pima Indians and Caucasians. J. Clin. Endocrinol. Metab. 73:866-876.

14. Le Stunff, C., and Bougneres, P. 1992. Early changes in postprandial insulin secretion, not in insulin sensitivity, characterize juvenile obesity. Diabetes. 43:696-702.

15. Jeanrenaud, B. 1994. Central nervous system and peripheral abnormalities: clues to the understanding of obesity and NIDDM. Diabetologia. 37(Suppl. 2):S170-S178

16. Zarjevski, N., Doyle, P., and Jeanrenaud, B. 1992. Muscle insulin resistance may not be a primary etiological factor in the genetically obese $f a / f a$ rat. Endocrinology. 130:1564-1570.

17. Kanety, H., Moshe, S., Shafrir, E., Lunenfeld, B., and Karasik, A. 1994. Hyperinsulinemia induces a reversible impairment in insulin receptor function leading to diabetes in the sand rat model of non-insulin-dependent diabetes mellitus. Proc. Natl. Acad. Sci. USA. 91:1853-1857.

18. Del Prato, S., et al. 1994. Effect of sustained physiologic hyperinsulinaemia and hyperglycaemia on insulin secretion and insulin sensitivity in man. Dia betologia. 37:1025-1035

19. Pontiroli, A.E., Alberetto, M., and Pozza, G. 1992. Patients with insulinoma show insulin resistance in the absence of arterial hypertension. Diabetologia. 35:294-295.

20. Skrha, J., Sindelka, G., Haas, T., Hilgertova, J., and Justova, V. 1996. Comparison of insulin sensitivity in patients with insulinoma and obese Type 2 diabetes mellitus. Horm. Metab. Res. 28:595-598.

21. Marban, S.L., DeLoia, J.A., and Gearhart, J.D. 1989. Hyperinsulinemia in transgenic mice carrying multiple copies of the human insulin gene. Dev Genet. 10:356-364.

22. Marban, S.L. 1992. Hyperinsulinemia precedes insulin resistance in transgenic mouse model of type II diabetes. Diabetes. 41(Suppl.):145A. (Abstr.)

23. Stempien, M.M., Fong, N.M., Rall, L.B., and Bell, G.I. 1986. Sequence of a placental cDNA encoding the mouse insulin-like growth factor II precursor. DNA. 5:357-361.

24. Valera, A., et al. 1994. Expression of Glut- 2 antisense RNA in $\beta$-cells of transgenic mice leads to diabetes. J. Biol. Chem. 269:28543-28546.

25. Hogan, B., Costantini, F., and Lacy, E. 1986. Manipulating the mouse embryo. A laboratory manual. Cold Spring Harbor Laboratory Press. Cold Spring Harbor. New York, NY. 157-173.

26. Chirgwin, J.M., Przybyla, A.W., McDonald, R.J., and Rutter, W.J. 1979. Isolation of biologically active ribonucleic acid from sources enriched in ribonucleases. Biochemistry. 18:5294-5299.

27. Lacy, P.E., and Kostianousky, M. 1967. Method for the isolation of intact islets of Langerhans from the rat pancreas. Diabetes. 16:35-39.

28. Ashcroft, S.J., Weeransinghe, L.C.C., Bassett, J.M., and Randle, P.J. 1972. The pentose cycle and insulin release in mouse pancreatic islets. Biochem. $J$. 126:525-532.

29. Fehmann, H.C., Jehle, P., Markus, U., and Goke, B. 1996. Functional active receptors for insulin-like growth factor-I (IGF-I) and IGF-II on insulin-, glucagon-, and somatostatin-producing cells. Metabolism. 45:759-766.

30. Tokuyama, Y., et al. 1995. Evolution of $\beta$-cell dysfunction in the male Zucker diabetic fatty rat. Diabetes. 44:1447-1457.

31. Polonsky, K.S. 1995. The $\beta$-cell in diabetes: from molecular genetics to clinical research. Diabetes. 44:705-717.

32. Larsson, L.I., Boder, G.B., and Shaw, W.N. 1977. Changes in the islets of Langerhans in the obese Zucker rat. Lab. Invest. 36:593-598.

33. Shino, A., Matsueo, T., Iwatsuka, H., and Zuzuki, Z. 1973. Structural changes of pancreatic islets in genetically obese rats. Diabetologia. 9:413-421.

34. Like, A.A., and Chick, W.L. 1970. Studies in the diabetic mutant mouse: elecron microscopy of pancreatic islets. Diabetologia. 6:216-242.

35. Van Schravendijk, C.F.H., Foriers, A., Van den Brande, J.L., and Pipeleers, D.G. 1987. Evidence for the presence of type 1 insulin-like growth factor receptors on rat pancreatic A and B cells. Endocrinology. 121:1784-1788.

36. Withers, D.J., et al. 1999. Irs- 2 coordinates Igf- 1 receptor-mediated $\beta$-cell development and peripheral insulin signalling. Nat. Genet. 23:32-40.

37. Coleman, D.L., and Hummel, K.P. 1973. The influence of genetic background on the expression of the obese $(o b)$ gene in the mouse. Diabetologia. 9:287-293.

38. Bruning, J.C., et al. 1997. Development of a novel polygenic model of NIDDM in mice heterozygous for IR and IRS-1 null alleles. Cell. 21:561-572.

39. Bonner-Weir, S., Deery, D., Leahy, J.L., and Weir, G.C. 1989. Compensatory growth of pancreatic B-cells in adult rats after short term glucose infusion. Diabetes. 38:49-53.

40. Araki, E., et al. 1994. Alternative pathway of insulin signalling in mice with targeted disruption of the IRS-1 gene. Nature. 372:186-190.

41. Tamemoto, H., et al. 1994. Insulin resistance and growth retardation in mice lacking insulin receptor substrate-1. Nature. 372:182-186.

42. Withers, D.J., et al. 1998. Disruption of IRS-2 causes type 2 diabetes. Nature. 391:900-903.

43. De Meyts, P., et al. 1994. The insulin-like growth factor-1 receptor. Structure, ligand-binding mechanism and signal transduction. Horm. Res. 42:152-169.

44. LeRoith, D., Werner, H., Beitner-Johnson, D., and Roberts, C.T. 1995. Molecular and cellular aspects of the insulin-like growth factor 1 receptor. Endocr. Rev. 16:143-163.

45. Mottola, C., and Czech, M.P. 1984. The type II insulin-like growth factor receptor does not mediate increased DNA synthesis in $\mathrm{H}-35$ hepatoma cells. J. Biol. Chem. 259:12705-12713.

46. Haig, D., and Graham, C. 1991. Genomic imprinting and the strange case of the insulin-like growth factor II receptor. Cell. 64:1045-1046.

47. Forejt, J., and Gregorova, S. 1992. Genetic analysis of genomic imprinting: an imprintor-1 gene controls inactivation of the paternal copy of the mouse Tme locus. Cell. 70:443-450.

48. Morrione, A., et al. 1997. Insulin-like growth factor II stimulates cell proliferation through the insulin receptor. Proc. Natl. Acad. Sci. USA. 94:3777-3782.

49. Kulkarni, R.N., et al. 1999. Tissue-specific knockout of the insulin receptor in pancreatic $\beta$ cells creates an insulin secretory defect similar to that in type 2 diabetes. Cell. 96:329-339.

50. Valera, A., et al. 1993. Glucose metabolism in transgenic mice containing a chimeric P-enolpyruvate carboxykinase/bovine growth hormone gene. FASEB J. 7:791-800.

51. Petrik, J., et al. 1999. Overexpression of insulin-like growth factor-II in transgenic mice is associated with pancreatic islet cell hiperplasia. Endocrinology. 140:2353-2363.

52. Cohen, P., et al. 1992. Insulin-like growth factors (IGFs): implications for aging. Psyconeuroendocrinology. 17:335-342.

53. Rogler, C.E., et al. 1994. Altered body composition and increased frequency of diverse malignancies in insulin-like growth factos-II transgenic mice.J. Biol. Chem. 269:13779-13784.

54. Rossetti, L., et al. 1996. Hepatic overexpression of insulin-like growth factorII in adulthood increases basal and insulin-stimulated glucose disposal in conscious mice. J. Biol. Chem. 271:203-208.

55. Leahy, J.L., and Vandekerkhove, K.M. 1990. Insulin-like growth factor-I at physiological concentrations is a potent inhibitor of insulin secretion. Endocrinology. 126:1593-1598.

56. Dheen, S.T., Rajkumar, K., and Murphy, L.J. 1996. Effects of insulin-like growth factors (IGF) on pancreatic islet function in IGF binding protein-1 transgenic mice. Diabetologia. 39:1249-1254.

57. Unger, R.H. 1995. Lipotoxicity in the pathogenesis of obesity-dependent NIDDM. Diabetes. 44:863-870.

58. Lee, Y., et al. 1994. $\beta$-cell lipotoxicity in the pathogenesis of non-insulindependent diabetes mellitus of obese rats: impairment in adipocyte- $\beta$-cell relationships. Proc. Natl. Acad. Sci. USA. 91:10878-10882

59. Milburn, J.L., et al. 1995. Pancreatic $\beta$-cell in obesity. J. Biol. Chem. 270:1295-1299. 